\title{
Epidemiological Surveillance of Communicable Diseases in Baghdad City during the Period January-April 2006
}

\author{
Adil R. Kadhim *, Ali H. Abbas**, Istabraq A. H. Mubarak***
}

Date of acceptance 5/4/2008

\section{Abstract}

The records of Primary Health Care Centres (Al-Risafa section of Baghdad) were inspected for communicable diseases during the period January-April 2006. There were 8622 recorded cases (the diagnosis was based on a clinical examination and laboratory findings), which were distributed as 4782 (55.5\%), 1430 (16.6\%), 1604 (18.6\%) and 806 (9.3\%) for Sadar city, Risafa, A'adhamyiah and Mada'in, respectively. The highest frequency was reported for chicken pox $(42.7 \%)$, followed by mumps and typhoid fever (20 and $13.7 \%$, respectively), while diphtheria and cholera were not recorded. These three most frequent diseases were further analyzed, and their distribution showed a significant difference $(\mathrm{P} \leq 0.001)$. April was the month of the highest recorded cases $(48.05 \%)$, followed by March (18.8\%), January (18.1\%) and finally February (14.7\%).

\section{Introduction:}

The World Health Organization (WHO) believes that epidemiological surveillance is an important element of communicable disease control programmes, and it is the cornerstone of epidemi- ology and preventive medicine(1).In this regard,the epidemiological surveillance is defined as ongoing and organized efforts that aim to act and/or initiate programmes for the control of communicable diseases that emerge in the population, furthermore, it is involved in preventing their incide$\mathrm{n}$ ce and to evaluate the results (2).The programme includes integrated activities, which cover collection, analysis and publishing of data. The collection of data includes information about infected cases, time and place of emergence, or what is called epidemiological triangle. The collected data then is analyzed and interpreted to get information about the aetiological agents that cause the disease(3).Accordingly, the present study was designed to shed light on the communicable diseases in Baghdad during the period January-April 2006

\section{Subjects and Methods}

The present study is descriptive, and its information was collected from the records of Primary Health Care Centres located in AlRisafa section of the capital Baghdad during the period January-April 2006.
The diagnosis was based on a clinical examination and labo-ratory findings.The cases were distributed on four sectors, which were Sadar city,Risafa,A'adhamyiah and Mada'in.The inspected communicable diseases were acute flaccid paralysis,diphtheria ,whopping cough,measles,mumps, neonatal tetanus,chicken pox,typhoid fever,cholera, cutaneous leishmaniasis,visceral leishmaniasis,toxoplasmosis,hydatid cysts,brucellosis, meningitis,viral hepatitis and pneumonia.The data was presented in terms of numbers and percentage frequencies, while the statistical analysis of the most frequent diseases was carried out using Chi-square test $\left(\mathrm{X}^{2}\right)$.

\section{Results}

There were 8622 recorded cases of communicable diseases, which were distributed as $4782(55.5 \%), 1430$ (16.6\%), 1604 (18.6\%) and $806(9.3 \%)$ for Sadar city, Risafa ,A'adhamyiah and Mada'in,respectively. The highest frequency was reported for chicken pox $(42.7 \%)$, followed by mumps and typhoid fever (20 and $13.7 \%$, respectively), while diphtheria and cholera were not recorded during the investigated period (Table 1).April was the month of the highest recorded cases (48.05\%),followed by $\operatorname{March}(18.8 \%)$ ,January (18.1\%) and finally February (14.7\%) (data not shown).

\footnotetext{
* Tropical-Biological Research Unit, College of Science, University of Baghdad 
The three most frequent diseases (chicken pox, mumps and typhoid fever) were further analyzed,and their numbers and percentage frequencies, together with Chisquare analysis, are given in table2.The distribution of these diseases showed a significant difference $(\mathrm{P} \leq 0.001)$. Such significancy was contributed mainly by Sadar city, in which more than $50 \%$ of the cases were occurred $(59.6 \%)$.

\section{Discussion}

The observed recorded numbers may not represent the actual picture of communicable disease profile in the investigated area,especially those cases that required no hospital admission, but they may help to und-erstand the background scope of these dis- eases in Al-Risafa section of the capital Baghdad. The study did not consider the age of infected cases, because the information was poor in this regard, although most of the causes of younger ages (children with an age range of 1-5 years).

The recorded number of cases (8622) represents $3.8 \%$ of the total recorded diseases in this section of Baghdad (unpublished information of Iraqi Ministry of Health in 2006). Such percentage is approximated the recorded frequencies in other Arabic countries;for instance, Yemen (4.5\%) and Sudan (3.9\%) (4), but it is higher than that of Europe $(0.2 \%)$ and Japan (1.1\%) (5). This can be explained by the fact that the latter countries are taking the necessary health managements, which enable them to prevent these diseases.

The highest frequency of recorded diseases was observed in Sadar city, and this is related the population impact and dynamics in this area, moreover, a low level of hygiene considerations together with an imperfect sewage system and poor sanitation are further augment the transmission of communicable diseases and increase their frequency. The chicken pox was the most frequent disease in this area, and this expected because the infection can be easily transmitted, furthermore, there is no effective vaccine against the causative factor of the disease.

In order to understand the epidemiological task of the recorded diseases for the first quarter of 2006, the recorded frequencies of mumps were compared with those recorded during the years 2002, 2004 and 2005. In the present study the mumps was observed with a frequency of $20 \%$, while it was $3.2,5.7$ and $15.4 \%$ for the years 2002,2004 and 2005,respectively(6).Such a gradual increase,especially for the years 2005 and 2006, may reflect the current poor health considerations, which assist in the transmission of the disease.The same arguments can be held true for other diseases, especially typhoid fever, which was one of the three most frequent diseases.

Other diseases (hydatid cysts, visceral leishmaniasis and cutaneous leshmaniasis) were observed with a low frequency; however, such findings may not represent the real incidence of these diseases.This is explained by the fact that these diseases are not diagnosed or treated in the Primary Health Care centres,rather they are managed in the hospitals.

Based on the finding of the present study, the following recommendations can be suggested:

- Make the vaccines available perfectly and update them for all ages, with a special reference to younger ones, according to the publications of WHO.

- Microscopical and chemical examination of tap water must be carried routinely, especially in end stage areas.

- The epidemiological surveillance must be updated quarterly each year, and such manipulation assist in designing the necessary progammes to control communicable diseases.

\section{References}

[1]Al-Momen,A.K.,N.M. Gadder,M.E.Ali, 1994.Prevention of communicable diseases. WHO Report, pp. 1-12.

[2]Snyder,J.D.,H.M.Michael,1992.The magnitude of the global problem of acute infectious diseases, a review of active surveillance data.WHO Bulletin,60:605-613.

[3] Abram, S., E. Benenson, 2001. Control of communicable diseases in man, $17^{\text {th }} \mathrm{ed}$, Al-Dawody Press, p. 409.

[4] Abdul Karim,M.1999.Pattern of adult medical admissions to a general hospital in Yemen. Saudi Medical Journal,20:386389. 
[5]Zukerman,A.J.1992.Perspectives in infectious diseases (The Proceeding of Interface Symposium, New challenges in the Blood Bank Screening Environment), Paris, pp. 26-27.

[6]Al-jailawy, M. H. (2004) Epidemiological Study of Mumps in Baghdad, Iraqi Journal of Preventive Medicine, 1:1-5.

Table 1: Observed numbers and percentage frequencies of communicable diseases in Al-Risafa section of Baghdad during the period January-April 2006.

\begin{tabular}{|c|c|c|c|c|c|c|c|}
\hline \multirow{2}{*}{\multicolumn{2}{|c|}{ Communicable Diseases }} & \multicolumn{4}{|c|}{$\begin{array}{l}\text { Al-Risafa Sectors } \\
\end{array}$} & \multicolumn{2}{|c|}{ Total } \\
\hline & & $\begin{array}{c}\text { Sadar } \\
\text { city }\end{array}$ & Risafa & A'adhamyiah & Mada'in & No. & $\%$ \\
\hline \multicolumn{2}{|c|}{ Acute flaccid paralysis } & 10 & - & 1 & 3 & 14 & 0.16 \\
\hline \multicolumn{2}{|c|}{ Diphtheria } & - & - & - & - & - & - \\
\hline \multicolumn{2}{|c|}{ Whopping cough } & 285 & 9 & 8 & 14 & 316 & 3.7 \\
\hline \multicolumn{2}{|c|}{ Measles } & 61 & 6 & 23 & 32 & 122 & 1.4 \\
\hline \multicolumn{2}{|c|}{ Mumps } & 1204 & 109 & 349 & 66 & 1728 & 20.0 \\
\hline \multicolumn{2}{|c|}{ Neonatal tetanus } & 1 & - & - & - & 1 & 0.01 \\
\hline \multicolumn{2}{|c|}{ Chicken pox } & 1885 & 775 & 848 & 174 & 3682 & 42.7 \\
\hline \multicolumn{2}{|c|}{ Typhoid fever } & 661 & 88 & 140 & 289 & 1178 & 13.7 \\
\hline \multicolumn{2}{|c|}{ Cholera } & - & - & - & - & - & - \\
\hline \multicolumn{2}{|c|}{ Cutaneous leishmaniasis } & 4 & 2 & 1 & 1 & 8 & 0.09 \\
\hline \multicolumn{2}{|c|}{ Visceral leishmaniasis } & 7 & - & 2 & 13 & 22 & 0.26 \\
\hline \multicolumn{2}{|c|}{ Toxoplasmosis } & 26 & 10 & 5 & 6 & 47 & 0.55 \\
\hline \multicolumn{2}{|c|}{ Hydatid cysts } & 4 & 2 & 4 & 3 & 13 & 0.15 \\
\hline \multicolumn{2}{|c|}{ Brucellosis } & 7 & 9 & 10 & 6 & 32 & 0.37 \\
\hline \multicolumn{2}{|c|}{ Meningitis } & 5 & 1 & 0 & 13 & 19 & 0.22 \\
\hline \multicolumn{2}{|c|}{ Viral hepatitis } & 214 & 287 & 126 & 125 & 752 & 8.7 \\
\hline \multicolumn{2}{|c|}{$\begin{array}{l}\text { Pneumonia } \\
\end{array}$} & 408 & 132 & 87 & 61 & 688 & 7.9 \\
\hline \multirow{2}{*}{ Total } & No. & 4782 & 1430 & 1604 & \multicolumn{2}{|c|}{806} & \multirow{2}{*}{8622} \\
\hline & $\%$ & 55.5 & 16.6 & 18.6 & \multicolumn{2}{|c|}{9.3} & \\
\hline
\end{tabular}

Table 2: The three most frequent communicable diseases in AlRisafa section of Baghdad during the period January-April 2006. $\mathrm{X}^{2}=837.9 ;$ D.F. $=6 ; \mathrm{P} \leq 0.001$

\begin{tabular}{|c|c|c|c|c|c|c|c|c|}
\hline \multirow{2}{*}{$\begin{array}{c}\text { Al- } \\
\text { Risafa } \\
\text { Sectors }\end{array}$} & \multicolumn{6}{|c|}{ Communicable Diseases } & \multicolumn{2}{|c|}{ Total } \\
\cline { 2 - 8 } & \multicolumn{2}{|c|}{ Chicken pox } & \multicolumn{2}{|c|}{ Mumps } & \multicolumn{2}{|c|}{ Typhoid fever } & \multicolumn{2}{|c|}{} \\
\cline { 2 - 8 } & No. & $\%$ & No. & $\%$ & No. & $\%$ & No. & $\%$ \\
\hline $\begin{array}{c}\text { Sadar } \\
\text { city }\end{array}$ & 1885 & 51.2 & 1204 & 69.7 & 661 & $\begin{array}{c}56 . \\
1\end{array}$ & 3750 & 56.9 \\
\hline Risafa & 775 & 21.0 & 109 & 6.3 & 88 & 7.5 & 972 & 14.8 \\
\hline $\begin{array}{c}\text { A'adham } \\
\text { yiah }\end{array}$ & 848 & 23.0 & 349 & 20.2 & 140 & $\begin{array}{c}11 . \\
9\end{array}$ & 1337 & 20.3 \\
\hline Madain & 174 & 4.7 & 66 & 3.8 & 289 & $\begin{array}{c}24 . \\
5\end{array}$ & 529 & 8.0 \\
\hline Total & 3682 & 55.9 & 1728 & 26.2 & 1178 & $\begin{array}{c}17 . \\
9\end{array}$ & \multicolumn{2}{|c|}{6588} \\
\hline
\end{tabular}

\section{الرصد الوبائي للأمر اض الانتقالية في مدينة بغداد للفترة كانون الثاني- نيسان 2006 \\ عادل رضيوي كاظمثّ، علي حافظ عباس، أستبرق عبل الهادي مبارك}

* وحدة الابحاث البايولوجية للمناطق الحارة / كلية العلوم / جامعة بغداد

الخلاصة

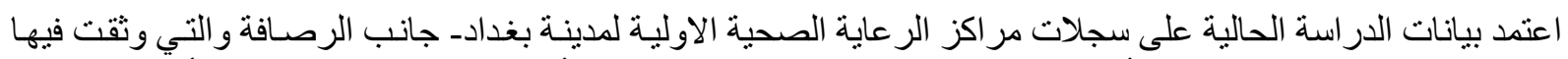

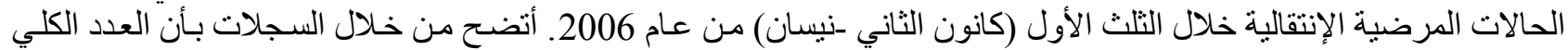

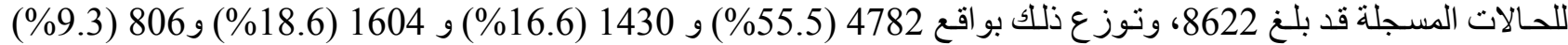

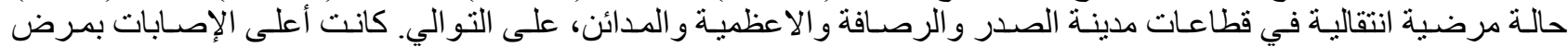

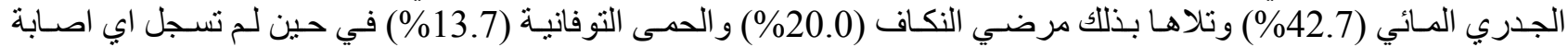

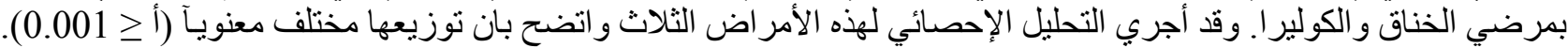

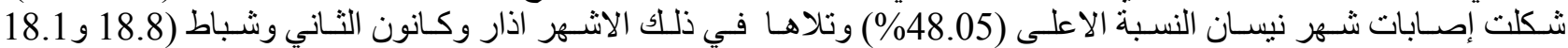

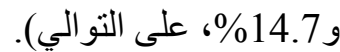

